\title{
Early Life Stress and the Onset of Obesity: Proof of MicroRNAs' Involvement Through Modulation of Serotonin and Dopamine Systems' Homeostasis
}

\author{
Gabriel Araujo Tavares ${ }^{1,2 *}$, Amada Torres ${ }^{1,3}$ and Julliet Araujo de Souza ${ }^{4}$ \\ 'Nantes Université, INRAE, UMR 1280, PhAN, Nantes, France, ${ }^{2}$ Laboratory of Neuroplasticity and Behavior, Graduate \\ Program of Nutrition, Federal University of Pernambuco, Recife, Brazil, ${ }^{3}$ Developmental Genetics and Molecular Physiology, \\ Instituto de Biotecnologia, Universidad Nacional Autonoma de Mexico - Campus Morelos, Cuernavaca, Mexico, \\ ${ }^{4}$ Laboratory of Neuroplasticity and Behavior, Graduate Program of Neuropsychiatry and Behavioral Sciences, Federal \\ University of Pernambuco, Recife, Brazil
}

\section{OPEN ACCESS}

Edited by:

Hanna Taipaleenmäki,

University Medical Center Hamburg-Eppendorf, Germany

Reviewed by:

Stefano Bastianini,

University of Bologna, Italy

Yuval Sillberman,

Pennsylvania State University, United States

*Correspondence:

Gabriel Araujo Tavares gabrieltavaresufpe@outlook.com

Specialty section: This article was submitted to Integrative Physiology, a section of the journal

Frontiers in Physiology

Received: 22 May 2020 Accepted: 09 July 2020

Published: 28 July 2020

Citation:

Tavares GA, Torres A and de Souza JA (2020) Early Life Stress

and the Onset of Obesity: Proof of MicroRNAs' Involvement Through Modulation of Serotonin

and Dopamine Systems Homeostasis. Front. Physiol. 11:925. doi: 10.3389/fphys.2020.00925
Healthy persons hold a very complex system for controlling energy homeostasis. The system functions on the interconnected way between the nutritional, endocrine, neural, and epigenetic regulation, which includes the microRNAs (miRNAs). Currently, it is well accepted that experiences of early life stress (ELS) carry modification of the central control of feeding behavior, one of the factors controlling energy homeostasis. Recently, studies give us a clue on the modulation of eating behavior, which is one of the main factors associated with the development of obesity. This clue connected the neural control through the serotonin $(5 \mathrm{HT})$ and dopamine (DA) systems with the fine regulation of miRNAs. The first pieces of evidence highlight the presence of the miR-16 in the regulation of the serotonin transporter (SERT) as well as the receptors 1a (5HT1A) and 2a (5HT2A). On the other hand, miR-504 is related to the dopamine receptor D2 (DRD2). As our knowledge advance, we expected to discover other important pathways for the regulation of the energy homeostasis. As both neurotransmission systems and miRNAs seem to be sensible to ELS, the aim of this review is to bring new insight about the involvement of miRNAs with a central role in the control of eating behavior focusing on the influences of ELS and regulation of neurotransmission systems.

\section{Keywords: miRNA, early life stress, obesity, serotonin, dopamine}

Abbreviations: 3'UTR, 3'Untranslated region; 5HT, 5-Hydroxytryptamine, serotonin system; 5HT1A, 5Hydroxytryptamine receptor 1A; 5HT1B, 5-Hydroxytryptamine receptor 1B; 5HT2C, 5-Hydroxytryptamine receptor 2C; 5HT4, 5-Hydroxytryptamine receptor 4; 5HT6, 5-Hydroxytryptamine receptor 6; 5HT7, 5-Hydroxytryptamine receptor 7; AgRP, protein related to gene agouti; cAMP, cyclic adenosine monophosphate; CART, cocaine and amphetamine-related transcript; CpGs, methylated cytosines follow of guanine nucleotide sites; CUMS, chronic unpredictable mild-life stress; CUS, chronic unpredictable stress; DA, dopamine, dopamine system; DAT, solute carrier family 6, neurotransmitter transporter dopamine member 3, SLC6A3; Dicer, microRNA-processing ribonuclease III; DRD1, dopamine receptor D1; DRD2, dopamine receptor D2; DRD3, dopamine receptor D3; DRD5, dopamine receptor D5; ELS, early life stress; EW, early weaning; has-mir-16, MI0000070, MI0000115; Let-7d, hsa-let-7d-5p, mmu-let-7d-5p, rno-let-7d-5p (MIMAT0000065, MIMAT0000383, MIMAT0000562); miR-103, has-mir-103a-1 MI0000109, has-mir-103a-2 MI0000108; miR-143-3p, hsa-miR-143-3p, mmu-miR-143-3p, rno-miR-143-3p (MIMAT0000435, MIMAT0000247, MIMAT0000849); miR-16-5p, hsa-miR-16-5p, mmu-miR-16-5p, rno-miR-16-5p (MIMAT0000069, MIMAT0000527, MIMAT0000785); miR-200a, rno-miR-200a-3p, mmu-miR-200a-3p, hsa-miR-200a-3p (MIMAT0000682, MIMAT0000519, MIMAT0000874); miR96, hsa-miR-96-5p, mmu-miR-96-5p, rno-miR-96-5p (MIMAT0000095, MIMAT0000541, MIMAT0000818); miRNAs, microRNAs; mmu-miR-135, MI0000161, MI0000715; mPFC, medial pre-frontal cortex; mRNA, Messenger RNA; MS, maternal separation; NAcc, nucleus accumbens; NPY, neuropeptide Y; PLC, prelimbic cortex; PND, postnatal day; POMC pro-opiomelanocortin; REST, repressor element-1 silencing transcription factor; RNAs, ribonucleic acids; SERT, solute carrier family 6 member 4 (SLC6A4/5HTT), serotonin transporter; TH, tyrosine hydroxylase. 


\section{INTRODUCTION}

Almost over one-third of the world's population is overweight or obese (Chooi et al., 2019). This condition negatively affects the life quality, productivity, and costs with public health. One of the main aspects of this body weight regulation is feeding behavior (Remmers and Delemarre-van de Waal, 2011) which involves neural networks such as the serotonergic (5HT) and dopaminergic (DA) systems (Meguid et al., 2000). Several studies show that the disruption of those systems is strongly associated with increased food intake and/or preference for palatable food, which are important factors contributing for the onset of obesity (van Galen et al., 2018). Gene expression of both 5HT and DA systems can be influenced by miRNAs (Launay et al., 2011; Shi et al., 2014), and in this case, they would be the key regulatory molecules in the comprehension of the pathophysiology of the feeding behavior.

MiRNAs are small non-coding RNAs with an average length of approximately 22 nucleotides (Bartel, 2004). They regulate post-transcriptional gene expression by binding to the $3^{\prime}$ UTR of mRNAs, some miRNAs also regulate the expression of another or several other miRNAs (Truscott et al., 2016), and even themselves (Zisoulis et al., 2012). Generally, miRNA specifically inhibit protein synthesis either by repressing translation or by inducing deadenylation and degradation of target mRNA (Bartel, 2004) but were also reported to activate translation (Huntzinger and Izaurralde, 2011). Each miRNA has the capacity to target hundreds of diverse transcripts, and a single messenger can be modulated by several miRNAs, this represents a highly coordinated system and fine-tuned regulation of protein expression (Krol et al., 2010; O'Carroll and Schaefer, 2013).

On the other hand, a healthy environment during the beginning of life is crucial for a proper development in mammals (Resnick et al., 1979; Morgane et al., 1993 2002). Maternal nutritional and emotional factors are critical during periconceptional and perinatal periods (Morgane et al., 1993; Chen and Baram, 2016). Early life stress (ELS) experiences can lead to long-term neurobehavioral complications. Both pre-clinical and clinical studies identify the influence of ELS on the development of several psychiatric disorders, including perturbation of feeding behavior, eating disorders and obesity (Chen and Baram, 2016; Entringer et al., 2016). Interestingly, the miRNAs are also sensible to ELS through several models, as showed on Table 1. In this context, this review brings a potential role of the miRNAs in the onset of obesity through modulation of $5 \mathrm{HT}$ and DA in response to ELS.

\section{SEROTONIN: ROLE ON FEEDING BEHAVIOR, INFLUENCES OF ELS, AND MIRNA REGULATION}

The 5HT system includes receptors, transporters and enzymes involved in the metabolism of serotonin (5-Hydroxytryptamine), and it regulates several functions in the organism as locomotors activity, body temperature, wake-sleep cycle, and feeding behavior (Lam et al., 2010; Olivier, 2015). Regarding the control of eating behavior, serotonin has a well-established anorectic role through promotion of satiety. In the arcuate nucleus of the hypothalamus, serotonin acts in different ways; it acts on $5 \mathrm{HT} 1 \mathrm{~B}$, promoting inhibition of neurons that produce neuropeptide Y (NPY) and the cocaine and amphetaminerelated transcript (CART), which are orexigenic. It also acts on $5 \mathrm{HT} 2 \mathrm{C}$, promoting activation of neurons that produce pro-opiomelanocortin (POMC) and the peptide related to the agouti gene (AgRP), which are anorexigenic, thus promoting satiety signaling (Heisler et al., 2006). In addition, recent studies also refer that serotonin has a role in the hedonic regulation of eating behavior. Receptors such as 5HT6 in areas of the mesocorticolimbic circuit have been associated with motivational feeding behavior (da Silva et al., 2017). The impairments of the homeostasis of the serotonergic system are associated with disorders of eating behavior, usually associated with increased food intake, either by homeostatic or hedonic changes. In particular, the serotonergic system appears extremely sensitive to environmental changes during the development of the organism, and several studies have shown that ELS impairs the function of the 5HT system (de Lima et al., 2020).

Models of ELS in animals are usually associated with deprivation of the mother-infant relationship, such as in maternal separation (MS) and early weaning (EW) models (Kikusui and Mori, 2009; Harrison and Baune, 2014). Previous studies from our laboratory show that the MS disrupts the $5 \mathrm{HT}$ system. In middle aged females, it increases the 5HT1B gene expression in the hypothalamus, associated with decreased food intake (de Souza et al., 2020a), and in adult males, we observed a decreased action of fluoxetine on food intake (de Souza et al., 2020b). In addition, MS promotes decreased 5HT concentration in hypothalamus and amygdala of young animals, associated with increased palatable food intake (de Lima et al., 2020). Together, these data suggest that MS alter the serotonergic system function, contributing to disorders of feeding behavior. On the other hand, we have been able to associate the EW with changes in gene expression of several components of the 5HT system in male and female rats, such as SERT, 5HT1B, and 5HT2C in hypothalamus and brainstem. Based on the patterns of expression in the brainstem and response to fenfluramine, we suggested a hypofunction of the serotonergic system in the EW animals (Tavares et al., 2019, 2020a,b). All these changes in the 5-HT system were accompanied by alterations on feeding behavior, which indicate that the 5HT system control of feeding behavior can be modulated by ELS, which can be directly linked to the onset of obesity.

Recently, studies have deepened about these compensatory changes and epigenetic modifications have been extensively investigated. In this respect, miRNAs have been shown to be important regulators $y / 0$ mediators of gene expression. In the case of depression, it is currently accepted that several miRNAs modulate the activity of the serotonergic system, but little is known about these regulators in the context of eating behavior. As far as we know, miR-16 is able to bind the SERT messenger 
TABLE 1 | Influences of ELS on miRNA activity.

\begin{tabular}{|c|c|c|c|c|}
\hline ELS model & Subjects & Region & Outcome & Authors \\
\hline \multicolumn{5}{|l|}{ Pre-clinical studies } \\
\hline MS & Rat & Hippocampus & Increased miR-16 & Bai et al., 2012 \\
\hline MS & Mice & Cortical neurons & $\begin{array}{l}\text { Impaired response of miR-212 to the learning } \\
\text { process on a cocaine conditioned place } \\
\text { preference test }\end{array}$ & Viola et al., 2016 \\
\hline $\mathrm{MS}+\mathrm{CUS}$ & Rat & NAcc & Increased miR-504 & Zhang et al., 2013 \\
\hline MS & Rat & mPFC & Increased REST4 & Uchida et al., 2010 \\
\hline Morphine + Apnea + MS & Mice & Hippocampus & $\begin{array}{l}\text { Decreased miR-204-5p, miR-455-3p, } \\
\text { miR-448-5p, and miR-574-3p }\end{array}$ & McAdams et al., 2015 \\
\hline CUMS & Rat & Basolateral amygdala & Increased rno-miR-124a & Xu et al., 2017 \\
\hline Increased maternal care & Rat & Hypothalamus & $\begin{array}{l}\text { increased rno-miR-488, rno-miR-144, and } \\
\text { rno-miR-542-5p and decreased rno-miR-421 } \\
\text { and rno-miR-376b-5p }\end{array}$ & Vogel Ciernia et al., 2018 \\
\hline Protein malnutrition & Mice & Hypothalamus & $\begin{array}{l}\text { increased mmu-miR-187-3p, } \\
\text { mmu-miR-369-3p and mmu-miR-132-3p }\end{array}$ & Berardino et al., 2019 \\
\hline $\begin{array}{l}\text { Unpredictable maternal } \\
\text { separation combined with } \\
\text { maternal stress }\end{array}$ & Mice & Sperm & Changes in miRNA transmitted to F2 generation & Gapp et al., 2014 \\
\hline Prenatal stress & Rat & Hippocampus & Decreased hsa-miR-125b-1-3p & Cattane et al., 2019 \\
\hline \multicolumn{5}{|l|}{ Clinical studies } \\
\hline Childhood maltreatment & both sexes & Leukocytes & $\begin{array}{l}\text { Methylation changes in CpGs close to region } \\
\text { coding miR-124-3 }\end{array}$ & Prados et al., 2015 \\
\hline Childhood abuse & $\begin{array}{l}\text { Men aged } 45 \text { years } \\
\text { old }\end{array}$ & Whole blood & $\begin{array}{l}\text { Methylation changes in promoter region of } 39 \\
\text { miRNAs }\end{array}$ & Suderman et al., 2014 \\
\hline Child abuse & $\begin{array}{l}\text { European adults of } \\
\text { both sexes }\end{array}$ & Buccal mucosa cells & $\begin{array}{l}\text { Association between the polymorphism rs } 3125 \\
\text { of } 5 \text { HT2A and brooding. This region is } \\
\text { predicted to be targeted by miR-1270, } \\
\text { miR-1304, miR-202, miR-539 and miR- } 620\end{array}$ & Eszlari et al., 2019 \\
\hline Childhood trauma & Adult of both sexes & Blood cells & Decreased hsa-miR-125b-1-3p & Cattane et al., 2019 \\
\hline Childhood trauma & Adult both sexes & $\begin{array}{l}\text { Human hippocampus } \\
\text { progenitor cells }\end{array}$ & Decreased hsa-miR-125b-1-3p & Cattane et al., 2019 \\
\hline
\end{tabular}

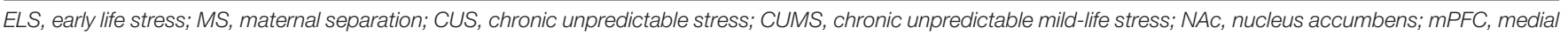
pre-frontal cortex; CpGs, methylated cytosines followed by guanine nucleotide sites.

(Table 2) and silence its expression in humans and animals (Baudry et al., 2010; Moya et al., 2013; Song et al., 2015; Shao et al., 2018). The relationship between miR-16 and SERT is even modulated by pharmacological antidepressant treatment and also alternative treatments as the electroacupuncture; besides different responses according to the affected brain area, these treatments improve the level of depressive behaviors, suggesting a highly specific regulation (Baudry et al., 2010; Zhao et al., 2019). SERT appears to be a key piece of regulation, as different miRNAs can modify its expression, as the mmu-miR-135 (Issler et al., 2014), rno-miR-18a-5p, rno-miR-34a-5p, rno-miR-135a5p, rno-miR-195-5p, rno-miR-320-3p, rno-miR-674-3p, and rnomiR-872-5p (Zurawek et al., 2017). This relationship between miR-16 and SERT is interesting, since SERT activity is directly related to serotonergic signaling. SERT recaptures the remaining amount of serotonin from the synaptic clefts, and an increase in its activity may mean a decrease in serotonergic signaling. In depression, has been shown that decreased levels of miR-16 and elevated levels of SERT are associated with the pathology by promoting a reduction in serotonergic signaling. Drugs that block SERT activity and increase serotonin levels are used to treat this depressive behavior. Interestingly, the same drugs are used to treat obesity (Halford et al., 2012) as they also promote a reduction in food intake. This evidence gives a primary role to miR-16 that may also be a candidate to modulate SERT activity in the context of eating disorders.

In addition to SERT, miRNAs modulate the activity of other components of the serotonergic system (Table 2), such as 5HT1B, 5HT1A, 5HT4, 5HT2C, and 5HT7. The 5HT1B receptor is advised as a target of the miR-96 (Jensen et al., 2009). 5HT1A seems to be targeted by miR-16, miR-135 (Liu et al., 2017), and has-miR-26a-2 (Xie et al., 2019). The 5HT4 receptor acquire decreased expression in response to miR-103, has-miR-15b and a mix containing hsa-miR-103, has-miR-15b and hsa-miR-16 (Wohlfarth et al., 2017). In addition, miR-34 appears to bind the receptor 5HT2C (Andolina et al., 2016), hsa-miR-16 appears to reduce 5HT2A expression (Yang et al., 2017), and miR29a decreases the expression of 5HT7 (Volpicelli et al., 2019). The impairment of the activity of these receptors is associated with disrupted food intake either by homeostatic or hedonic mechanisms. 5HT1A, 5HT1B, and 5HT2C are strongly associated with satiety signaling, and several studies report that their 
TABLE 2 | Components of the serotonergic and dopaminergic systems and their regulatory-associated miRNAs.

\begin{tabular}{|c|c|c|}
\hline Components & miRNAs & Authors \\
\hline \multicolumn{3}{|c|}{ Serotonin or 5 -Hydroxytryptamine $(5 \mathrm{HT})$ system } \\
\hline $\begin{array}{l}\text { SERT } \\
\text { (SLC6A4/5HTT) }\end{array}$ & $\begin{array}{l}\text { miR-16, miR-135, } \\
\text { miR-18a-5p, miR-34a-5p, } \\
\text { miR-135a-5p, miR-195-5p, } \\
\text { miR-320-3p, miR-674-3p, } \\
\text { and miR-872-5p. }\end{array}$ & $\begin{array}{l}\text { Baudry et al., 2010; Launay } \\
\text { et al., 2011; Moya et al., 2013; } \\
\text { Issler et al., 2014; Song et al., } \\
\text { 2015; Zurawek et al., } 2017 \text {; } \\
\text { Shao et al., 2018; Zhao et al., } \\
2019\end{array}$ \\
\hline $5 \mathrm{HT} 1 \mathrm{~A}$ & $\begin{array}{l}\text { miR-16, miR-135, and } \\
\text { miR-26a-2. }\end{array}$ & Liu et al., 2017; Xie et al., 2019 \\
\hline $5 \mathrm{HT} 1 \mathrm{~B}$ & $\operatorname{miR}-96$ & Jensen et al., 2009 \\
\hline $5 \mathrm{HT} 2 \mathrm{~A}$ & $\operatorname{miR}-16$ & Yang et al., 2017 \\
\hline $5 \mathrm{HT} 2 \mathrm{C}$ & miR-34 & Andolina et al., 2016 \\
\hline $5 \mathrm{HT} 4$ & $\begin{array}{l}\text { miR-103, miR- } 15 b \text {, and a } \\
\text { mix containing miR-103, } \\
\text { miR-15b, and miR-16 }\end{array}$ & Wohlfarth et al., 2017 \\
\hline $5 \mathrm{HT7}$ & $\operatorname{miR}-29 a$ & Volpicelli et al., 2019 \\
\hline \multicolumn{3}{|c|}{ Dopamine (DA) system } \\
\hline DRD1 & $\begin{array}{l}\text { miR-504, miR-105, } \\
\text { miR-15a, miR-15b, miR-16 } \\
\text { and miR-142-3p }\end{array}$ & $\begin{array}{l}\text { Tobón et al., 2012, 2015; } \\
\text { Zhang et al., 2013; Zhao et al., } \\
\text { 2017; Wu et al., } 2020\end{array}$ \\
\hline DRD2 & $\begin{array}{l}\text { miR-143, miR-200a, } \\
\text { miR-504, has-miR-9 and } \\
\text { miR-326 }\end{array}$ & $\begin{array}{l}\text { Zhang et al., 2013, 2015; Shi } \\
\text { et al., 2014; Gangisetty et al., } \\
\text { 2017; Wu et al., 2018; } \\
\text { Mavrikaki et al., 2019; Wang } \\
\text { et al., } 2019\end{array}$ \\
\hline DRD3 & let-7d & Bahi and Dreyer, 2018 \\
\hline DAT & miR-137 and miR-491 & Jia et al., 2016 \\
\hline
\end{tabular}

SERT, solute carrier family 6 member 4 (SLC6A4/5HTT), serotonin transporter; 5HT1A, 5-Hydroxytryptamine receptor 1A; 5HT1B, 5-Hydroxytryptamine receptor 1B; 5HT2C, 5-Hydroxytryptamine receptor 2C; 5HT4, 5-Hydroxytryptamine receptor 4; 5HT7, 5-Hydroxytryptamine receptor 7; DRD1, dopamine receptor D1; DRD2, dopamine receptor D2; DRD3, dopamine receptor D3; DAT, dopamine transporter, solute carrier family 6 member 3 (SLC6A3).

disruption promotes increased food intake. On the other hand, $5 \mathrm{HT} 4$ is associated with hedonic modulation of food intake and obesity. Thus, the modulation of these receptors through miRNAs can also be associated with the onset of eating disorders leading to obesity.

\section{DOPAMINE: ROLE ON FEEDING BEHAVIOR, INFLUENCES OF ELS, AND MIRNA REGULATION}

The dopaminergic system, as well as the serotoninergic system, comprises a set of neurotransmitter, enzymes, receptors, and dopamine transporter (DAT). On the other hand, neurons that synthesize dopamine can be found in the brainstem and can be divided into three groups, which forms the Nigro Striatal system, the mesocorticolimbic system, and the mesocortical system (Ogawa and Watabe-Uchida, 2018). The principal role on feeding behavior is taken by the mesocorticolimbic system (Wise, 1989; Berridge and Kringelbach, 2008). Dopaminergic neurons are known to be involved in emotion-based behavior including motivation and reward (Phillips et al., 2008). Therefore, in the context of the feeding behavior, this system is mainly related to the hedonic component of feeding, but evidences also point out that dopamine is a key component on hypothalamic regulation of the homeostatic eating behavior (Meguid et al., 2000; Ikeda et al., 2018).

The DA system is sensible to ELS and its disruption is associated with several psychiatric disorders, such as eating disorders and obesity (Naef et al., 2015). Our previous study showed that DRD1 and DRD2 gene expression were increased in the brainstem of adult rats, accompanied by higher palatable food intake after MS (de Souza et al., 2018). The MS also modulates the DA system in other brain areas, such as PLC, NAcc, and striatum, changing the density of immunoreactive fibers of $\mathrm{TH}$, and the mRNA expression of DRD2, DRD1, and DRD5 (Majcher-Maślanka et al., 2017). On the other hand, EW increases DRD1 mRNA expression in the hypothalamus and brainstem and DRD2 in the brainstem of middle-aged male rats (Tavares et al., 2020b). In all of these studies, disrupted patterns on feeding behavior are observed, indicating that alterations in the dopaminergic system can be one of the underlying mechanisms that lead to behavioral disorders.

Increased evidence points out that several components of the dopaminergic system are influenced by some miRNAs (Table 2). DRD1 appears to be regulated by miR-504 (Zhang et al., 2013), rno-miR-105 (Zhao et al., 2017), and for the cluster of hsa-miR15a-5p, hsa-miR-15b-5p, and hsa-miR-16-5p, and mmu-miR142-3p (Tobón et al., 2012, 2015). The expression of the DRD2 is modified by miR-143-3p (Wang et al., 2019), miR-200a (Wu et al., 2018), miR-504 (Zhang et al., 2013), hsa-miR-9, and hsamiR-326 (Shi et al., 2014; Zhang et al., 2015; Gangisetty et al., 2017; Mavrikaki et al., 2019). Both receptors, DRD1 and DRD2, are associated with control of food intake, either homeostatic or hedonic, in several areas of the brain (Wise, 1989; Ikeda et al., 2018) which indicates that its modulation through miRNAs can modulate the food intake. In addition, overexpression of let-7d is negatively correlated with the expression of DRD3 in the hippocampus of mice (Bahi and Dreyer, 2018). The activity of the DRD3 is controversy in the context of food intake, but some evidences associate it with eating disorders and decreased food intake (Thomsen et al., 2017; González et al., 2019). The expression of DAT, the major controller of dopamine levels in the synaptic clefts, is post-transcriptionally regulated on cell culture of dopaminergic neurons by miR-137 and miR-491 (Jia et al., 2016). This transporter acts like SERT, reuptaking the dopamine from the synaptic cleft, so its function is extremely necessary to normal DA signalization, even in the context of eating behavior. On the other hand, the reduction of Dicer, a miRNA-processing ribonuclease III, in the ventral midbrain of DA neurons promotes changes in the miRNAs profile and altered the survival capacity of these dopaminergic neurons (Chmielarz et al., 2017). Together, these evidences extended the susceptibility of the DA system to the regulation of miRNAs, which can lead to modulation of eating behavior and may be associated with eating disorders. 


\section{PERSPECTIVES: ROLE OF THE MIRNAS ON THE ONSET OF OBESITY THROUGH 5HT AND DA SYSTEMS' DISRUPTION IN THE CONTEXT OF ELS}

In addition to knowing that components of the 5HT and DA neurotransmission systems are susceptible to ELS, some evidence also shows that miRNAs have their expression and activity influenced by ELS, which is summarized in Table 1 . Both, pre-clinical and clinical studies affirm that childhood trauma could be associated with the modulation of miRNA, as the case of the miR-16 and miR-504 which have their control of the serotonin and dopamine impaired by stress, with consequences such as depression, anhedonia, and body weight gain. However, more studies are needed to understand the full picture, specifically in the context of the control of the feeding behavior, which is directly involved in the development of obesity.

Conversely, both clinical and pre-clinical studies demonstrate that ELS is able to alter SERT activity (Wankerl et al., 2014; Van Der Knaap et al., 2015; Tavares et al., 2019, 2020a). Interestingly, differences in SERT activity are observed in obesity, both in humans and animals (Giannaccini et al., 2013; Borgers et al., 2014; Zha et al., 2017). For example, the density of SERT is reduced in obese humans (Giannaccini et al., 2013; Borgers et al., 2014) and increased in rats with abdominal obesity who were exposed to a diet rich in simple carbohydrates (Spadaro et al., 2015). In addition to being involved in the pathophysiology of obesity and being sensitive to ELS, several lines of evidence in the literature show that SERT is a target for miR-16 and propose an important role in regulating its activity (Baudry et al., 2010). On the other hand, animal studies demonstrate that the $5 \mathrm{HT} 1 \mathrm{~A}$ receptor is also modulated by ELS (Bravo et al., 2014; Razoux et al., 2017) and has increased density in the hippocampus and hypothalamus of rats chronically submitted to a Westernized diet (Yu et al., 2018). Interestingly, $5 \mathrm{HT} 1 \mathrm{~A}$ is also the target of miR-16, which has its expression modulated by ELS (Bai et al., 2012). The receptor $5 \mathrm{HT} 2 \mathrm{~A}$ is, as well, modulated by ELS in animals and humans (Rentesi et al., 2013; Parade et al., 2017) and involved with the pathophysiology of obesity (Rosmond et al., 2002; Huang et al., 2004). Interestingly, the 5HT2A is also targeted by the miR-16 (Yang et al., 2017). From these observations, we believe that miR16 is an excellent candidate for moderating changes in SERT, $5 \mathrm{HT} 1 \mathrm{~A}$, and 5HT2A due to ELS, in the context of the altered eating behavior.

Regarding the dopaminergic system, the DRD1 and DRD2 actively participate in the regulation of food intake, especially with regard to palatable foods, as these are related to the food reward system (Meguid et al., 2000; Berridge et al., 2009; Volkow et al., 2011). Changes in this reward system are linked to eating behavior disorders, with changes in the activity of DRD1 and DRD2 being observed in humans and animals (Guo et al., 2014; Rivera et al., 2015; Gaiser et al., 2016; de Souza et al., 2018; Romanova et al., 2018; Tavares et al., 2020b). In addition, both receptors are modulated by ELS (de Souza et al., 2018; Tavares et al., 2020b). Interestingly, we observed that miR-504 targets both DRD1 and DRD2, with their expression being altered by ELS (Zhang et al., 2015). Additionally, DRD1 has also been identified as a target for miR-16 (Wu et al., 2020). Thus, we believe that miR-504 and miR-16 modulate DRD1 and DRD2, in the context of eating disorders associated with ELS.

In summary, according to the evidence reported, we can infer that the serotonergic and dopaminergic systems undergo regulation of their activity through post-transcriptional modulation by miRNAs. Both systems participate in the physiological and pathological processes of eating behavior, which leads us to believe that miRNAs may be behind several changes in eating behavior as observed in several disorders such as obesity. Several studies point out that the genesis of these disorders is largely associated with experiences of stress early in life. Neonatal stress is already well described as a modulator of the serotonergic and dopaminergic systems associated with disorders of eating behavior, as well as a modulator of expression and activity of miRNAs. In addition, we know that miRNAs participate in the pathological processes of several psychiatric disorders. Thus, we establish here a relationship between neonatal stress and the modulation of the serotonergic and dopaminergic systems, through post-transcriptional regulation by miRNAs, as a possible pathophysiological mechanism behind eating behavior disorders. Future studies are needed to investigate this relationship and provide further support for the scientific community in the search for understanding and treatment of pathologies of eating behavior.

\section{AUTHOR CONTRIBUTIONS}

All authors listed have made a substantial, direct and intellectual contribution to the work, and approved it for publication.

\section{FUNDING}

This work was carried out with the financial support of the regional program "RFI Food for Tomorrow/Cap Aliment and Research, Education, and Innovation in Pays de la Loire," which was supported by the French Region Pays de la Loire, the European Regional Development Fund (FEDER). Additionally, this study was financed in part by the Coordenação de Aperfeiçoamento de Pessoal de Nível Superior - Brasil (CAPES) Finance Code 001.

\section{ACKNOWLEDGMENTS}

The authors would like to thank Rudah Goes and Tayná Goes for helping with the design of the graphical abstract and Dr. Bertrand Kaeffer for the comments to the manuscript. 


\section{REFERENCES}

Andolina, D., Di Segni, M., Bisicchia, E., D’Alessandro, F., Cestari, V., Ventura, A., et al. (2016). Effects of lack of microRNA-34 on the neural circuitry underlying the stress response and anxiety. Neuropharmacology 107, 305-316. doi: 10.1016/ j.neuropharm.2016.03.044

Bahi, A., and Dreyer, J. L. (2018). Lentiviral-mediated let-7d microRNA overexpression induced anxiolytic- and anti-depressant-like behaviors and impaired dopamine D3 receptor expression. Eur. Neuropsychopharmacol. 28, 1394-1404. doi: 10.1016/j.euroneuro.2018.09.004

Bai, M., Zhu, X., Zhang, Y., Zhang, S., Zhang, L., Xue, L., et al. (2012). Abnormal hippocampal BDNF and miR-16 expression is associated with depression-like behaviors induced by stress during early life. PLoS One 7:e46921. doi: 10.1371/ journal.pone.0046921

Bartel, D. P. (2004). MicroRNAs: genomics, biogenesis, mechanism, and function. Cell 116, 281-297. doi: 10.1016/S0092-8674(04)00045-5

Baudry, A., Mouillet-Richard, S., Schneider, B., Launay, J. M., and Kellermann, O. (2010). MiR-16 targets the serotonin transporter: a new facet for adaptive responses to antidepressants. Science 329, 1537-1541. doi: 10.1126/science. 1193692

Berardino, B. G., Chertoff, M., Gianatiempo, O., Alberca, C. D., Priegue, R., Fiszbein, A., et al. (2019). Exposure to enriched environment rescues anxiety-like behavior and miRNA deregulated expression induced by perinatal malnutrition while altering oligodendrocyte morphology. Neuroscience 408, 115-134. doi: 10.1016/j.neuroscience.2019.03.027

Berridge, K. C., and Kringelbach, M. L. (2008). Affective neuroscience of pleasure: reward in humans and animals. Psychopharmacology 199, 457-480. doi: 10. 1007/s00213-008-1099-6

Berridge, K. C., Robinson, T. E., and Aldridge, J. W. (2009). Dissecting components of reward: "liking", "wanting", and learning. Curr. Opin. Pharmacol. 9, 65-73. doi: 10.1016/j.coph.2008.12.014

Borgers, A. J., Koopman, K. E., Bisschop, P. H., Serlie, M. J., Swaab, D. F., Fliers, E., et al. (2014). Decreased serotonin transporter immunoreactivity in the human hypothalamic infundibular nucleus of overweight subjects. Front. Neurosci. 8:106. doi: 10.3389/fnins.2014.00106

Bravo, J. A., Dinan, T. G., and Cryan, J. F. (2014). Early-life stress induces persistent alterations in $5-\mathrm{HT}_{1 \mathrm{~A}}$ receptor and serotonin transporter mrna expression in the adult rat brain. Front. Mol. Neurosci. 7:24. doi: 10.3389/fnmol.2014. 00024

Cattane, N., Mora, C., Lopizzo, N., Borsini, A., Maj, C., Pedrini, L., et al. (2019). Identification of a miRNAs signature associated with exposure to stress early in life and enhanced vulnerability for schizophrenia: new insights for the key role of miR-125b-1-3p in neurodevelopmental processes. Schizophr. Res. 205, 63-75. doi: 10.1016/j.schres.2018.07.030

Chen, Y., and Baram, T. Z. (2016). Toward understanding how earlylife stress reprograms cognitive and emotional brain networks. Neuropsychopharmacology 41, 197-206. doi: 10.1038/npp.2015.181

Chmielarz, P., Konovalova, J., Najam, S. S., Alter, H., Piepponen, T. P., Erfle, H., et al. (2017). Dicer and microRNAs protect adult dopamine neurons. Cell Death Dis. 8:e2813. doi: 10.1038/cddis.2017.214

Chooi, Y. C., Ding, C., and Magkos, F. (2019). The epidemiology of obesity. Metabolism. 92, 6-10. doi: 10.1016/j.metabol.2018.09.005

da Silva, A. A. M., Oliveira, M. M., Cavalcante, T. C. F., do Amaral Almeida, L. C., Cruz, P. L. M., and de Souza, S. L. (2017). Undernutrition during pregnancy and lactation increases the number of fos-cells in the reward system in response to a 5-HT6 receptor agonist in male adolescent rats. Int. J. Food Sci. Nutr. 69, 488-493. doi: 10.1080/09637486.2017.1382455

de Lima, R. M. S., dos Santos, Bento, L. V., di Marcello Valladão Lugon, M., Barauna, V. G., Bittencourt, A. S., et al. (2020). Early life stress and the programming of eating behavior and anxiety: sex-specific relationships with serotonergic activity and hypothalamic neuropeptides. Behav. Brain Res. 379:112399. doi: 10.1016/j.bbr.2019.112399

de Souza, J. A., da Silva, M. C., Costa, F. C. O., de Matos, R. J. B., de Farias Campina, R. C., do Amaral Almeida, L. C., et al. (2020a). Early life stress induced by maternal separation during lactation alters the eating behavior and serotonin system in middle-aged rat female offspring. Pharmacol. Biochem. Behav. 192:172908. doi: 10.1016/j.pbb.2020.172908

de Souza, J. A., do Amaral Almeida, L. C., Tavares, G. A., Falcão, L. A. L., Beltrão, L. C., et al. (2020b). Dual exposure to stress in different stages of development affects eating behavior of male Wistar rats. Physiol. Behav. 214:112769. doi: 10.1016/j.physbeh.2019.112769

de Souza, J. A., da Silva, M. C., de Matos, R. J. B., do Amaral Almeida, L. C., Beltrão, L. C., de Souza, F. L., et al. (2018). Pre-weaning maternal separation increases eating later in life in male and female offspring, but increases brainstem dopamine receptor 1a and 2a only in males. Appetite 123, 114-119. doi: 10.1016/ j.appet.2017.12.004

Entringer, S., Buss, C., and Heim, C. (2016). Early-life stress and vulnerability for disease in later life. Bundesgesundheitsblatt Gesundheitsforschung Gesundheitsschutz 59, 1255-1261. doi: 10.1007/s00103-016-2436-2

Eszlari, N., Petschner, P., Gonda, X., Baksa, D., Elliott, R., Anderson, I. M. et al. (2019). Childhood adversity moderates the effects of HTR2A Epigenetic regulatory polymorphisms on rumination. Front. Psychiatry 10:394. doi: 10. 3389/fpsyt.2019.00394

Gaiser, E. C., Gallezot, J. D., Worhunsky, P. D., Jastreboff, A. M., Pittman, B., Kantrovitz, L., et al. (2016). Elevated dopamine $\mathrm{D}_{2 / 3}$ receptor availability in obese individuals: a PET imaging study with $\left[{ }^{11} \mathrm{C}\right](+)$ PHNO. Neuropsychopharmacology 41, 3042-3050. doi: 10.1038/npp.2016.115

Gangisetty, O., Jabbar, S., Wynne, O., and Sarkar, D. K. (2017). MicroRNA-9 regulates fetal alcohol-induced changes in D2 receptor to promote prolactin production. J. Endocrinol. 235, 1-14. doi: 10.1530/joe-17-0135

Gapp, K., Jawaid, A., Sarkies, P., Bohacek, J., Pelczar, P., Prados, J., et al. (2014). Implication of sperm RNAs in transgenerational inheritance of the effects of early trauma in mice. Nat. Neurosci. 17, 667-669. doi: 10.1038/nn.3695

Giannaccini, G., Betti, L., Palego, L., Marsili, A., Santini, F., Pelosini, C., et al. (2013). The expression of platelet serotonin transporter (SERT) in human obesity. BMC Neurosci. 14:128. doi: 10.1186/1471-2202-14-128

González, L. M., Mota-Zamorano, S., García-Herráiz, A., López-Nevado, E., and Gervasini, G. (2019). Genetic variants in dopamine pathways affect personality dimensions displayed by patients with eating disorders. Eat. Weight Disord. doi: 10.1007/s40519-019-00820-7 [Epub ahead of print].

Guo, J., Simmons, W. K., Herscovitch, P., Martin, A., and Hall, K. D. (2014). Striatal dopamine D2-like receptor correlation patterns with human obesity and opportunistic eating behavior. Mol. Psychiatry 19, 1078-1084. doi: 10.1038/mp. 2014.102

Halford, J., Harrold, J., Lawton, C., and Blundell, J. (2012). Serotonin (5-HT) drugs: effects on appetite expression and use for the treatment of obesity. Curr. Drug Targets 6, 201-213. doi: 10.2174/1389450053174550

Harrison, E. L., and Baune, B. T. (2014). Modulation of early stress-induced neurobiological changes: a review of behavioural and pharmacological interventions in animal models. Transl. Psychiatry 4:e390. doi: 10.1038/tp. 2014.31

Heisler, L. K., Jobst, E. E., Sutton, G. M., Zhou, L., Borok, E., Thornton-Jones, Z., et al. (2006). Serotonin reciprocally regulates melanocortin neurons to modulate food intake. Neuron 51, 239-249. doi: 10.1016/j.neuron.2006.06.004

Huang, X. F., Han, M., and Storlien, L. H. (2004). Differential expression of 5- $\mathrm{HT}_{2 \mathrm{~A}}$ and $5-\mathrm{HT}_{2 \mathrm{C}}$ receptor mRNAs in mice prone, or resistant, to chronic high-fat diet-induced obesity. Mol. Brain Res. 127, 39-47. doi: 10.1016/j.molbrainres. 2004.05.008

Huntzinger, E., and Izaurralde, E. (2011). Gene silencing by microRNAs: contributions of translational repression and mRNA decay. Nat. Rev. Genet. 12, 99-110. doi: 10.1038/nrg2936

Ikeda, H., Yonemochi, N., Ardianto, C., Yang, L., and Kamei, J. (2018). Pregabalin increases food intake through dopaminergic systems in the hypothalamus. Brain Res. 1701, 219-226. doi: 10.1016/j.brainres.2018.09.026

Issler, O., Haramati, S., Paul, E. D., Maeno, H., Navon, I., Zwang, R., et al. (2014). MicroRNA 135 is essential for chronic stress resiliency, antidepressant efficacy, and intact serotonergic activity. Neuron 83, 344-360. doi: 10.1016/j.neuron. 2014.05.042

Jensen, K. P., Covault, J., Conner, T. S., Tennen, H., Kranzler, H. R., and Furneaux, H. M. (2009). A common polymorphism in serotonin receptor 1B mRNA moderates regulation by miR-96 and associates with aggressive human behaviors. Mol. Psychiatry 14, 381-389. doi: 10.1038/mp.2008.15

Jia, X., Wang, F., Han, Y., Geng, X., Li, M., Shi, Y., et al. (2016). miR-137 and miR491 negatively regulate dopamine transporter expression and function in neural cells. Neurosci. Bull. 32, 512-522. doi: 10.1007/s12264-016-0061-6

Kikusui, T., and Mori, Y. (2009). Behavioural and neurochemical consequences of early weaning in rodents. J. Neuroendocrinol. 21, 427-431. doi: 10.1111/j.13652826.2009.01837.x 
Krol, J., Loedige, I., and Filipowicz, W. (2010). The widespread regulation of microRNA biogenesis, function and decay. Nat. Rev. Genet. 11, 597-610. doi: $10.1038 / \mathrm{nrg} 2843$

Lam, D. D., Garfield, A. S., Marston, O. J., Shaw, J., and Heisler, L. K. (2010). Brain serotonin system in the coordination of food intake and body weight. Pharmacol. Biochem. Behav. 97, 84-91. doi: 10.1016/j.pbb.2010.09.003

Launay, J. M., Mouillet-Richard, S., Baudry, A., Pietri, M., and Kellermann, O. (2011). Raphe-mediated signals control the hippocampal response to SRI antidepressants via miR-16. Transl. Psychiatry 1:e56. doi: 10.1038/tp.2011.54

Liu, Y., Liu, D., Xu, J., Jiang, H., and Pan, F. (2017). Early adolescent stress-induced changes in prefrontal cortex miRNA-135a and hippocampal miRNA-16 in male rats. Dev. Psychobiol. 59, 958-969. doi: 10.1002/dev.21558

Majcher-Maślanka, I., Solarz, A., Wêdzony, K., and Chocyk, A. (2017). The effects of early-life stress on dopamine system function in adolescent female rats. Int. J. Dev. Neurosci. 57, 24-33. doi: 10.1016/j.ijdevneu.2017.01.001

Mavrikaki, M., Anastasiadou, E., Ozdemir, R. A., Potter, D., Helmholz, C., Slack, F. J., et al. (2019). Overexpression of miR-9 in the nucleus accumbens increases oxycodone self-administration. Int. J. Neuropsychopharmacol. 22, 383-393. doi: 10.1093/ijnp/pyz015

McAdams, R. M., McPherson, R. J., Beyer, R. P., Bammler, T. K., Farin, F. M., and Juul, S. E. (2015). Dose-dependent effects of morphine exposure on mRNA and microRNA ( $\mathrm{miR}$ ) expression in hippocampus of stressed neonatal mice. PLoS One 10:e123047. doi: 10.1371/journal.pone.0123047

Meguid, M. M., Fetissov, S. O., Varma, M., Sato, T., Zhang, L., Laviano, A., et al. (2000). Hypothalamic dopamine and serotonin in the regulation of food intake. Nutrition 16, 843-857. doi: 10.1016/S0899-9007(00)00449-4

Morgane, P. J., Austin-LaFrance, R., Bronzino, J., Tonkiss, J., Díaz-Cintra, S., Cintra, L., et al. (1993). Prenatal malnutrition and development of the brain. Neurosci. Biobehav. Rev. 17, 91-128.

Morgane, P. J., Mokler, D. J., and Galler, J. R. (2002). Effects of prenatal protein malnutrition on the hippocampal formation. Neurosci. Biobehav. Rev. 26, 471483. doi: 10.1016/S0149-7634(02)00012-X

Moya, P. R., Wendland, J. R., Salemme, J., Fried, R. L., and Murphy, D. L. (2013). MiR-15a and miR-16 regulate serotonin transporter expression in human placental and rat brain raphe cells. Int. J. Neuropsychopharmacol. 16, 621-629. doi: $10.1017 /$ S1461145712000454

Naef, L., Pitman, K. A., and Borgland, S. L. (2015). Mesolimbic dopamine and its neuromodulators in obesity and binge eating. CNS Spectr. 20, 574-583. doi: $10.1017 /$ S1092852915000693

O'Carroll, D., and Schaefer, A. (2013). General principals of miRNA biogenesis and regulation in the brain. Neuropsychopharmacology 38, 39-54. doi: 10.1038/npp. 2012.87

Ogawa, S. K., and Watabe-Uchida, M. (2018). Organization of dopamine and serotonin system: anatomical and functional mapping of monosynaptic inputs using rabies virus. Pharmacol. Biochem. Behav. 174, 9-22. doi: 10.1016/j.pbb. 2017.05.001

Olivier, B. (2015). Serotonin: a never-ending story. Eur. J. Pharmacol. 753, 2-18. doi: 10.1016/j.ejphar.2014.10.031

Parade, S. H., Novick, A. M., Parent, J., Seifer, R., Klaver, S. J., Marsit, C. J., et al. (2017). Stress exposure and psychopathology alter methylation of the serotonin receptor 2A (HTR2A) gene in preschoolers. Dev. Psychopathol. 29, 1619-1626. doi: 10.1017/S0954579417001274

Phillips, A. G., Vacca, G., and Ahn, S. (2008). A top-down perspective on dopamine, motivation and memory. Pharmacol. Biochem. Behav. 90, 236-249. doi: 10. 1016/j.pbb.2007.10.014

Prados, J., Stenz, L., Courtet, P., Prada, P., Nicastro, R., Adouan, W., et al. (2015). Borderline personality disorder and childhood maltreatment: a genome-wide methylation analysis. Genes Brain Behav. 14, 177-188. doi: 10.1111/gbb.12197

Razoux, F., Russig, H., Mueggler, T., Baltes, C., DIkaiou, K., Rudin, M., et al. (2017). Transgenerational disruption of functional $5-\mathrm{HT}_{1 \mathrm{~A}} \mathrm{R}$-induced connectivity in the adult mouse brain by traumatic stress in early life. Mol. Psychiatry 22, 519-526. doi: 10.1038/mp.2016.146

Remmers, F., and Delemarre-van de Waal, H. A. (2011). Developmental programming of energy balance and its hypothalamic regulation. Endocr. Rev. 32, 272-311. doi: 10.1210/er.2009-0028

Rentesi, G., Antoniou, K., Marselos, M., Syrrou, M., Papadopoulou-Daifoti, Z., and Konstandi, M. (2013). Early maternal deprivation-induced modifications in the neurobiological, neurochemical and behavioral profile of adult rats. Behav. Brain Res. 244, 29-37. doi: 10.1016/j.bbr.2013.01.040
Resnick, O., Miller, M., Forbes, W., Hall, R., Kemper, T., Bronzino, J., et al. (1979). Developmental protein malnutrition: influences on the central nervous system of the rat. Neurosci. Biobehav. Rev. 3, 233-246. doi: 10.1016/0149-7634(79) 90011-3

Rivera, H. M., Kievit, P., Kirigiti, M. A., Bauman, L. A., Baquero, K., Blundell, P., et al. (2015). Maternal high-fat diet and obesity impact palatable food intake and dopamine signaling in nonhuman primate offspring. Obesity 23, 2157-2164. doi: 10.1002/oby.21306

Romanova, I. V., Derkach, K. V., Mikhrina, A. L., Sukhov, I. B., Mikhailova, E. V., and Shpakov, A. O. (2018). The leptin, dopamine and serotonin receptors in hypothalamic POMC-neurons of normal and obese rodents. Neurochem. Res. 43, 821-837. doi: 10.1007/s11064-018-2485-z

Rosmond, R., Bouchard, C., and Björntorp, P. (2002). 5- $\mathrm{HT}_{2 \mathrm{~A}}$ receptor gene promoter polymorphism in relation to abdominal obesity and cortisol. Obes. Res. 10, 585-589. doi: 10.1038/oby.2002.79

Shao, Q. Y., You, F., Zhang, Y. H., Hu, L. L., Liu, W. J., Liu, Y., et al. (2018). CSF miR-16 expression and its association with miR-16 and serotonin transporter in the raphe of a rat model of depression. J. Affect. Disord. 238, 609-614. doi: 10.1016/j.jad.2018.06.034

Shi, S., Leites, C., He, D., Schwartz, D., Moy, W., Shi, J., et al. (2014). MicroRNA-9 and microRNA-326 regulate human dopamine D2 receptor expression, and the microrna-mediated expression regulation is altered by a genetic variant. J. Biol. Chem. 289, 13434-13444. doi: 10.1074/jbc.M113. 535203

Song, M. F., Dong, J. Z., Wang, Y. W., He, J., Ju, X., Zhang, L., et al. (2015). CSF miR-16 is decreased in major depression patients and its neutralization in rats induces depression-like behaviors via a serotonin transmitter system. J. Affect. Disord. 178, 25-31. doi: 10.1016/j.jad.2015.02.022

Spadaro, P. A., Naug, H. L., Du Toit, E. F., Donner, D., and Colson, N. J. (2015). A refined high carbohydrate diet is associated with changes in the serotonin pathway and visceral obesity. Genet. Res. 97:e23. doi: 10.1017/ S0016672315000233

Suderman, M., Borghol, N., Pappas, J. J., Pinto Pereira, S. M., Pembrey, M., Hertzman, C., et al. (2014). Childhood abuse is associated with methylation of multiple loci in adult DNA. BMC Med. Genomics 7:13. doi: 10.1186/17558794-7-13

Tavares, G. A., Cavalcanti do Amaral Almeida, L., Araújo de Souza, J., Leitão de Souza, F., Feitosa Braz, G. R., Times Silva, B., et al. (2020a). Early weaning modulates eating behavior and promotes hypofunction of the serotonergic (5HT) system in juvenile male rats. Int. J. Dev. Neurosci. 80, 209-219. doi: 10.1002/jdn. 10018

Tavares, G. A., do Amaral Almeida, L. C., de Souza, J. A., de Farias, V. V., de Souza, F. L., de Andrade Silva, S. C., et al. (2020b). Early weaning leads to disruption of homeostatic and hedonic eating behaviors and modulates serotonin (5HT) and dopamine (DA) systems in male adult rats. Behav. Brain Res. 383:112531. doi: 10.1016/j.bbr.2020.112531

Tavares, G. A., do Amaral Almeida, L. C., de Souza, J. A., Feitosa Braz, G. R., da Silva, M. C., Lagranha, C. J., et al. (2019). Early weaning disrupts feeding patterns in female juvenile rats through 5HT-system modulations. Behav. Processes 170:103981. doi: 10.1016/j.beproc.2019.103981

Thomsen, M., Barrett, A. C., Butler, P., Negus, S. S., and Caine, S. B. (2017). Effects of acute and chronic treatments with dopamine $\mathrm{D}_{2}$ and $\mathrm{D}_{3}$ receptor ligands on cocaine versus food choice in rats. J. Pharmacol. Exp. Ther. 362, 161-176. doi: 10.1124/jpet.117.241141

Tobón, K. E., Catuzzi, J. E., Cote, S. R., Sonaike, A., and Kuzhikandathil, E. V. (2015). Post-transcriptional regulation of dopamine D1 receptor expression in caudate-putamen of cocaine-sensitized mice. Eur. J. Neurosci. 42, 1849-1857. doi: 10.1111/ejn.12933

Tobón, K. E., Chang, D., and Kuzhikandathil, E. V. (2012). MicroRNA 142-3p mediates post-transcriptional regulation of D1 dopamine receptor expression. PLoS One 7:e49288. doi: 10.1371/journal.pone.0049288

Truscott, M., Islam, A. B. M. M. K., and Frolov, M. V. (2016). Novel regulation and functional interaction of polycistronic miRNAs. RNA 22, 129-138. doi: 10.1261/rna.053264.115

Uchida, S., Hara, K., Kobayashi, A., Funato, H., Hobara, T., Otsuki, K., et al. (2010). Early life stress enhances behavioral vulnerability to stress through the activation of REST4-mediated gene transcription in the medial prefrontal cortex of rodents. J. Neurosci. 30, 15007-15018. doi: 10.1523/JNEUROSCI. $1436-10.2010$ 
Van Der Knaap, L. J., Riese, H., Hudziak, J. J., Verbiest, M. M. P. J., Verhulst, F. C., Oldehinkel, A. J., et al. (2015). Adverse life events and allele-specific methylation of the serotonin transporter gene (SLC6A4) in adolescents. Psychosom. Med. 77, 246-255. doi: 10.1097/PSY.0000000000000159

van Galen, K. A., ter Horst, K. W., Booij, J., la Fleur, S. E., and Serlie, M. J. (2018). The role of central dopamine and serotonin in human obesity: lessons learned from molecular neuroimaging studies. Metabolism 85, 325-339. doi: 10.1016/j.metabol.2017.09.007

Viola, T. W., Wearick-Silva, L. E., De Azeredo, L. A., Centeno-Silva, A., Murphy, C., Marshall, P., et al. (2016). Increased cocaine-induced conditioned place preference during periadolescence in maternally separated male BALB/c mice: the role of cortical BDNF, microRNA-212, and MeCP2. Psychopharmacology 233, 3279-3288. doi: 10.1007/s00213-016-4373-z

Vogel Ciernia, A., Laufer, B. I., Dunaway, K. W., Mordaunt, C. E., Coulson, R. L., Totah, T. S., et al. (2018). Experience-dependent neuroplasticity of the developing hypothalamus: integrative epigenomic approaches. Epigenetics 13, 318-330. doi: 10.1080/15592294.2018.1451720

Volkow, N. D., Wang, G. J., and Baler, R. D. (2011). Reward, dopamine and the control of food intake: implications for obesity. Trends Cogn. Sci. 15, 37-46. doi: 10.1016/j.tics.2010.11.001

Volpicelli, F., Speranza, L., Pulcrano, S., De Gregorio, R., Crispino, M., De Sanctis, C., et al. (2019). The microRNA-29a modulates serotonin 5-HT7 receptor expression and its effects on hippocampal neuronal morphology. Mol. Neurobiol. 56, 8617-8627. doi: 10.1007/s12035-019-01690-x

Wang, P., Cao, T., Chen, J., Jiang, Y., Wang, C., Waddington, J. L., et al. (2019). D2 receptor-mediated miRNA-143 expression is associated with the effects of antipsychotic drugs on phencyclidine-induced schizophreniarelated locomotor hyperactivity and with Neuregulin-1 expression in mice. Neuropharmacology 157:107675. doi: 10.1016/j.neuropharm.2019.107675

Wankerl, M., Miller, R., Kirschbaum, C., Hennig, J., Stalder, T., and Alexander, N. (2014). Effects of genetic and early environmental risk factors for depression on serotonin transporter expression and methylation profiles. Transl. Psychiatry. 4:e402. doi: 10.1038/tp.2014.37

Wise, R. (1989). Brain dopamine and reward. Annu. Rev. Psychol. 40, 191-225. doi: 10.1146/annurev.psych.40.1.191

Wohlfarth, C., Schmitteckert, S., Härtle, J. D., Houghton, L. A., Dweep, H., Fortea, M., et al. (2017). MiR-16 and miR-103 impact 5-HT4 receptor signalling and correlate with symptom profile in irritable bowel syndrome. Sci. Rep. 7:14680.

Wu, D. M., Wang, S., Wen, X., Han, X. R., Wang, Y. J., Shen, M., et al. (2018). Inhibition of microRNA-200a upregulates the expression of striatal dopamine receptor $\mathrm{d} 2$ to repress apoptosis of striatum via the cAMP/PKA signaling pathway in rats with Parkinson's disease. Cell. Physiol. Biochem. 51, 1600-1615. doi: 10.1159/000495649

Wu, X., Xu, F., Xia, X., Wang, B. J., and Yao, J. (2020). MicroRNA-15a, microRNA$15 \mathrm{~b}$ and microRNA-16 inhibit the human dopamine D1 receptor expression in four cell lines by targeting 3'UTR -12 bp to +154 bp. Artif. Cells Nanomed. Biotechnol. 48, 276-287. doi: 10.1080/21691401.2019.1703729

Xie, L., Chen, J., Ding, Y. M., Gui, X. W., Wu, L. X., Tian, S., et al. (2019). MicroRNA-26a-2 maintains stress resiliency and antidepressant efficacy by targeting the serotonergic autoreceptor HTR1A. Biochem. Biophys. Res. Commun. 511, 440-446. doi: 10.1016/j.bbrc.2019.02.078
Xu, J., Wang, R., Liu, Y., Liu, D., Jiang, H., and Pan, F. (2017). FKBP5 and specific microRNAs via glucocorticoid receptor in the basolateral amygdala involved in the susceptibility to depressive disorder in early adolescent stressed rats. J. Psychiatr. Res. 95, 102-113. doi: 10.1016/j.jpsychires.2017.08.010

Yang, Y., Hu, Z., Du, X., Davies, H., Huo, X., and Fang, M. (2017). miR16 and fluoxetine both reverse autophagic and apoptotic change in chronic unpredictable mild stress model rats. Front. Neurosci. 11:428. doi: 10.3389/ fnins.2017.00428

Yu, Y., Patch, C., Weston-Green, K., Zhou, Y., Zheng, K., and Huang, X. F. (2018). Dietary galacto-oligosaccharides and resistant starch protect against altered $\mathrm{CB} 1$ and 5-HT1A and 2A receptor densities in rat brain: implications for preventing cognitive and appetite dysfunction during a high-fat diet. Mol. Nutr. Food Res. 62:e1800422. doi: 10.1002/mnfr.201800422

Zha, W., Ho, H. T. B., Hu, T., Hebert, M. F., and Wang, J. (2017). Serotonin transporter deficiency drives estrogen-dependent obesity and glucose intolerance. Sci. Rep. 7:1137. doi: 10.1038/s41598-017-01291-5

Zhang, Y., Wang, Y., Wang, L., Bai, M., Zhang, X., and Zhu, X. (2015). Dopamine receptor D2 and associated microRNAs are involved in stress susceptibility and resistance to escitalopram treatment. Int. J. Neuropsychopharmacol. 18:pyv025. doi: 10.1093/ijnp/pyv025

Zhang, Y., Zhu, X., Bai, M., Zhang, L., Xue, L., and Yi, J. (2013). Maternal deprivation enhances behavioral vulnerability to stress associated with miR504 expression in nucleus accumbens of rats. PLoS One 8:e69934. doi: 10.1371/ journal.pone.0069934

Zhao, J., Tian, H., Song, H., Wang, X., Luo, T., Ai, L., et al. (2019). Effect of electroacupuncture on reuptake of serotonin via mirna-16 expression in a rat model of depression. Evid. Based Complement. Alternat. Med. 2019:7124318. doi: 10.1155/2019/7124318

Zhao, Y., Zhang, J., Yang, H., Cui, D., Song, J., Ma, Q., et al. (2017). Memory retrieval in addiction: a role for miR-105-mediated regulation of D1 receptors in $\mathrm{mPFC}$ neurons projecting to the basolateral amygdala. BMC Biol. 15:128. doi: 10.1186/s12915-017-0467-2

Zisoulis, D. G., Kai, Z. S., Chang, R. K., and Pasquinelli, A. E. (2012). Autoregulation of microRNA biogenesis by let-7 and Argonaute. Nature 486, 541-544. doi: 10.1038/nature11134

Zurawek, D., Kusmider, M., Faron-Gorecka, A., Gruca, P., Pabian, P., Solich, J., et al. (2017). Reciprocal microRNA expression in mesocortical circuit and its interplay with serotonin transporter define resilient rats in the chronic mild stress. Mol. Neurobiol. 54, 5741-5751. doi: 10.1007/s12035-0160107-9

Conflict of Interest: The authors declare that the research was conducted in the absence of any commercial or financial relationships that could be construed as a potential conflict of interest.

Copyright (c) 2020 Tavares, Torres and de Souza. This is an open-access article distributed under the terms of the Creative Commons Attribution License (CC BY). The use, distribution or reproduction in other forums is permitted, provided the original author(s) and the copyright owner(s) are credited and that the original publication in this journal is cited, in accordance with accepted academic practice. No use, distribution or reproduction is permitted which does not comply with these terms. 